munch the contents reflectively rather than swallow them whole, which is precisely what the work requires.

Every orthopaedic surgeon should keep this book on his shelf, so that he may browse through small sections in the quiet evenings and dig more deeply when he feels the need to approach a problem from a fresh angle.

\section{TEXTBOOK OF BRITISH SURGERY Vol. 4}

Edited by Sir Henry Souttar and J. C. Goligher. Pp. viii +699 , illustrated. London: William Heinemann Ltd. 1959. I05s.

The fourth and final volume of 'Textbook of British Surgery' deals with inflammation, injuries (including burns) and orthopaedics. For this volume the editors, Sir Henry Souttar and Professor J. C. Goligher have been fortunate to secure the co-operation of Mr. Norman Capener.

The 21 chapters have been written by 17 different authors so that some unevenness is inevitable. Particularly impressive are the sparkling lucidity of Mr. Osmond Clarke's chapter on 'Pain in the neck and arm,' the logical synthesis between pathology and clinical findings in the chapter on 'Inflammation and pyogenic infections,' the thoroughness and clarity of 'Burns' by Mr. John Watson, and the authority and wisdom of the contributions by Mr. Norman Capener, Professor J. I. P. James, Mr. E. N. Wardle and Mr. Leon Gillis. Such selection, however, is invidious and probably highly personal; throughout, the writing is clear, the information up-to-date and somethough not all-of the illustrations are very helpful.

It is evident that complete coverage of orthopaedics has not been attempted, for such subjects as flat foot, hallux valgus and hammer toe are not discussed. For orthopaedic surgeons, it is legitimate to question the proportions of the entire work. This volume is mainly devoted to orthopaedics and is one of four volumes; the proportion seems unduly small for what is by far the largest branch of surgery. In consequence it has been necessary to compress some subjects considerably; for example, fractures and dislocations occupy only 74 pages, apart from an additional 13 pages on mal-union.

There are also internal disproportions within the volume itself: thus, tumours of bone occupy 54 pages while the commoner disorders of the knee joint are disposed of in 14 . Yet, the limitations of space are by no means always a disadvantage, for in many instances they have imposed a conciseness which is admirable.

These detailed criticisms do not detract from the value of the volume as a whole which is a useful and well-produced compendium of modern orthopaedics.

\section{ANTIBIOTIC THERAPY FOR STAPHYLOCOCCAL DISEASES}

Edited by Henry Welch and Maxwell Finland. Pp. 208. Medical Encyclopedia Inc., New York. Distributed by Interscience Publications. \$4.50.

Antibiotic therapy for staphylococcal diseases provides a very full guide to the properties and uses of those antibiotics which are now frequently needed to treat disease due to the more antibiotic resistant strains of staphylococcus.

The introduction summarises the present staphylococcal problem. Dr. Welch points out that the majority of staphylococcal lesions do not require chemotherapy and makes a very salutary comparison between the present-day management of a case of typhoid and that of one of staphylococcal infection, and he ends with a summary of the properties of the more common antibiotics. The following chapters are written by a group of experts, writing one feels with a good personal knowledge of the drugs concerned. Erythromycin, Oleandomycin, Novobiocin, Ristocetin, Kanamycin and Vancomycin, are each discussed in separate chapters. It is perhaps a reflection of the American origin of the book that the chapter on Oleandomycin occupies one quarter of the whole. Although the accent is primarily on the staphylococcal application of these drugs, in describing them comment is also made on their other uses.

The final chapter by Dr. Finland sums up the previous chapters, and gives the book balance with regard to the merits or otherwise of the drugs described and their use in combination.

This book is easy to read and not overburdened with unnecessary detail. Although it contains the relevant theoretical facts it is essentially a practical book and should be well received by clinician and bacteriologist alike.

\section{BIOCHEMISTRY OF BLOOD IN HEALTH AND DISEASE}

By I. Newton Kugelmass, M.D., PhD., Sc.D. Pp. ix +543 , illustrated. Blackwell Scientific Publications, Oxford. 1959. I 26s.

This book has an ambitious object, stated in the preface, " to present the newer knowledge of human blood in health and disease in the light of chemical research, clinical experience and medical necessity'! The author has pursued his task with a catholic taste which has savoured such diverse subjects as vitamins, enzymes and hormones, each of which subjects has a chapter. The whole book abounds with facts and references are extremely copious; one could complain of their number and the uncritical manner in which some are included. As one might expect, the chapters on water and electrolyte metabolism are excellent and the chapter on blood clotting also reflects the author's special experience. Dr. Kugelmass has managed to maintain his interest throughout his wide subject and 
we must congratulate him on this thesaurus of quasi-biochemical information.

\section{HERITABLE DISORDERS OF CONNECTIVE TISSUE}

By Victor A. McKusick. St. Louis: C. V. Mosby Co., distributed in Great Britain by Henry Kimpton, London. 1960. 90s.

In the whole field of Medicine, it would be hard to pick a related series of problems more difficult than those considered in this book. The physiology of connective tissue is poorly understood; its chemistry is fragmentary; and it is not even certain that connective tissue can justifiably be treated as an entity. The inherited diseases of this enigmatic body component consist of a series of weird conditions, all rare, such as the Marfan and EhlersDanlos syndromes, osteogenesis imperfecta, pseudoxanthoma elasticum and the Hurler syndrome (gargoylism). Although these varied syndromes are readily recognisable in their fully-developed forms, patients frequently display only a few incomplete features. Since there are no specific biochemical tests at present available diagnosis has to be based on appraisal of the clinical phenomena alone, and hence is often uncertain. The medical geneticist has therefore to feel his way through a swamp of uncertainty, with only rare islets of fact on which to place his feet. The skill with which Dr. McKusick performs this difficult feat is really remarkable. Although primarily a clinician, he has marshalled what little is known of the biology and chemistry of connective tissue in a useful preliminary chapter; and in another, has provided a brilliant summary of what medical genetics is about, which should be read by any clinician who is thinking of entering this field. The remainder of the book is devoted to detailed clinical descriptions of the rare syndromes previously enumerated, together with a full account of what is known of their mode of inheritance. Anyone interested in this group of diseases will find this book quite indispensable.

\section{TRANSPLANTATION OF TISSUES, Vol. II}

Edited by Lyndon A. Peer. Pp. xiv +690 , illustrated. London: Baillière, Tindall \& Cox. 1959. I60s.

This volume is an up-to-date résumé of most of the relevant work on tissue and organ transplantation. Sections are contributed by specialists in the various fields covered and the aim of the book seems to be to provide the clinician with the salient features of this rapidly expanding field.

The difficulties in accomplishing this task are great since genetic, biochemical and especially immunological considerations, disciplines previously separated from each other and even more remote from clinical practice, are directly pertinent to tissue transplantation problems.

The editor has in the main succeeded in providing a comprehensive and readable book. The obvious defects of multiple authorship result in some repetition, a variable literary standard and occasionally disproportionate emphasis, for example 30 pages are devoted to transplantation of peritoneum, surely a very limited field, in which only autografts are of value and clinicians are already familiar with most of the applications cited.

There is an excellent chapter on the biological aspects of transplantation by Professor Medawar. This is lucid and stimulating and provides a sound scientific basis to the volume.

The references are very full and usually accurate. In some instances unhelpful historical work is mentioned apparently for the sake of completeness. In most chapters the historical backgrounds are very similar, initial early experiments on transplantation were performed with little or no distinction between autografts and homografts and interpretation of graft survival often rested on metaphysical criteria. Later work differentiated the essential technical problems of autografts from the immunological aspects of homografting. The repetition of this evolution in different chapters seems unnecessary.

Considerable space is devoted to anatomical and physiological factors that do not appear to be directly related to tissue transplantation.

A textbook on tissue transplantation is certainly due. This volume, in spite of some excessive and irrelevent content, does provide a pertinent discussion of the problems involved in experimental work and clinical applications of both autografts and homografts.

There are chapters on transplantation of the following tissues, skin, cornea, fat, nerves, teeth, blood vessels, endocrine glands, organs, peritoneum and cancer cells.

\section{THE CARE OF MINOR HAND INJURIES}

By A. E. Flatt. Pp. 266. St. Louis: The C.U. Mosby Co., distributed in Great Britain by Henry Kimpton, London. 1959. 71s. 6d.

The author has rightly criticised his own choice of title, inferring that there is no such thing as a minor injury where the hand is concerned.

The scope of this book has been restricted largely to the types of injury which can be treated in the out-patient department. As such it will be of great value to the Casualty Officer, and the Practitioner who may be obliged to treat most of his hand injuries without the resources of a large hospital at his doorstep.

The first section deals with the general principles of care and can only be criticised by someone having a rooted objection to the use of local anaesthetics.

The second section deals with the care of specific injuries and by virtue of the fact that each chapter is comprehensive, contains a lot of repetition. This 